\title{
Cross Border Approach Sebagai Alternatif Model Kebijakan Pembangunan Kawasan Perbatasan
}

\author{
Saru Arifin \\ Fakultas Hukum, Universitas Negeri Semarang \\ Kampus Sekaran, Gedung C-4, Gunungpati, Semarang Jawa Tengah \\ sars@staff.unnes.ac.id
}

\begin{abstract}
This research rises the problems as follows: First, which factors contribute to the ineffective implementation of border area development policy. Second, whether Cross Border Approach model as relevant policy alternative will be implemented in the border area development and what pre-requisites are needed. This research used field survey method with interview, observation, and literature study techniques. The analysis model was conducted interactively. The findings conclude: First, the factors used in the development policy model by the government is less relevant with the area characteristics, including bureaucracy culture which is still sectoral, weak authority of border management board, inconsistency between technical policy and the border development paradigm, and isolated geographical condition which needs extra-ordinary treatment. Second, cross border approach is quite strategic to be policy model alternative for border development with some of its strength, among many, the program discussed is beneficial for both parties, the program is interest-based and the implementation is responded quickly by the government without undergoing complicated sectoral level.
\end{abstract}

Key words : Policy, cross border approach, border community

\begin{abstract}
Abstrak
Penelitian ini mengangkat permasalahan: Pertama, faktor-faktor apa saja yang menyebabkan implementasi kebijakan pembangunan kawasan perbatasan belum bisa berjalan secara efektif? Kedua, apakah model Cross Border Approach sebagai alternatif kebijakan relevan diterapkan dalam pembangunan kawasan perbatasan, dan prasyarat apa saja yang dibutuhkannya. Penelitian ini menggunakan metode survei lapangan dengan teknik wawancara, observasi dan kajian pustaka. Model analisis dilakukan secara interaktif. Hasil penelitian ini menyimpulkan pertama, faktor-faktor yang menyebabkan model kebijakan pembangunan yang digunakan pemerintah kurang relevan dengan karakteristik kawasan diantaranya, kultur birokrasi yang masih sektoral, lemahnya wewenang badan pengelola perbatasan, inkonsistensi kebijakan teknis dengan paradigma pembangunan perbatasan, serta faktor kondisi geografis yang terisolir memerlukan penanganan yang extra-ordinary. Kedua, cross border approach cukup strategis dijadikan alternatif model kebijakan pembangunan perbatasan dengan beberapa kelebihannya, yaitu: program yang digagas saling menguntungkan kedua belah pihak, program disusun berbasis kebutuhan dan pelaksanakan program direspon dengan cepat oleh pemerintah tanpa melalui jenjang sektor yang rumit.
\end{abstract}

Kata kunci : Kebijakan, cross border approach, masyarakat perbatasan 


\section{Pendahuluan}

Pengelolaan perbatasan negara merupakan rangkaian akhir dari proses pembentukan perbatasan. Stephen B. Jhones, ${ }^{1}$ sebagai salah satu ahli di bidang Kajian Perbatasan Negara khususnya perbatasan darat menegaskan, bahwa aspek management (pengelolaan) perbatasan negara merupakan pekerjaan yang bersifat kontinu. Sebab, di dalam kegiatan pengelolaan tersebut menyangkut banyak aspek yang terkait dengan pelaksanaan kedaulatan negara itu sendiri, seperti pemeliharaan patok batas negara, lalu lintas orang dan barang, serta persoalan pertahanan dan keamanan negara itu sendiri. Oleh karena itu, sudah sewajarnya bila wilayah perbatasan memerlukan sebuah mekanisme pengelolaan yang terintegrasi dan berkesinambungan karena di ruang perbatasan tersebut akan selalu terjadi "pergesekan" atau interaksi dengan negara tetangga, baik positif maupun negatif.

Berbagai program pembangunan telah dilakukan oleh pemerintah untuk memajukan kawasan perbatasan, baik secara fisik maupun sosial-ekonomi dan budaya masyarakatnya. Namun demikian, kondisi perbatasan tidak banyak mengalami perubahan, terlebih untuk bersaing dengan pesatnya pembangunan kawasan perbatasan dari negara tetangga, seperti Sarawak Malaysia. ${ }^{2}$ Malaysia mampu membangun pusat-pusat pertumbuhan di perbatasannya melalui berbagai kegiatan ekonomi dan perdagangan yang telah memberikan keuntungan bagi pemerintah maupun masyarakatnya. ${ }^{3}$

Sementara masyarakat perbatasan, umumnya miskin dan secara ekonomi lebih berorientasi ke negara tetangga-dengan melakukan migrasi temporer maupun permanen dengan motif utama ekonomi, sebagaimana hal itu terjadi di sepanjang kawasan perbatasan Kalbar dengan Sarawak. ${ }^{4}$ Ironinya, stelsel pemerintahan dalam

${ }^{1}$ Sutisna, Lukita, dan Sumaryo, Boundary Making Theory dan Pengelolaan Perbatasan di Indonesia, Disampaikan pada Workshop Pengelolaan Wilayah Perbatasan, Jurusan Ilmu HI/UPN Veteran, Yogyakarta, 18 November 2008, hlm. 1-4.

${ }^{2}$ Bappeda, Program Aksi Pengelolaan Perbatasan Antar Negara Kalimantan Barat. Laporan Kajian, Bappeda Provinsi Kalimantan Barat, 2007.

${ }^{3}$ Lihat ulasan secara komprehensif dalam Bappenas, 2003. Strategi dan Model Pengembangan Wilayah Perbatasan, hasil Laporan Studi Direktorat Pengembangan Kawasan Khusus dan Tertinggal Deputi Bidang Otonomi Daerah dan Pengembangan Regional Badan Perencanaan Pembangunan Nasional, Jakarta; Supiadi, A. 2004, Masalab Penguasaan Tanah di Daerah Perbatasan Indonesia-Malaysia Kaitannya dengan Security Belt: Studi Kasus di Desa Entikong, Kecamatan Entikong, Kabupaten Sanggau, Provinsi Kalimantan Barat, Laporan Penelitian, Badan Pertanahan Nasional, Sekolah Tinggi Pertanahan Nasional, Yogyakarta; Kompas, Menerobos Negara Untuk Menjual Hasil Pertanian, 4 April 2008.

${ }^{4}$ Arifin, Migrasi Penduduk dan Implikasinya Terhadap Hankam di Wilayah Perbatasan Kalbar-Serawak, Malaysia, Jurnal Masalah-Masalab Hukum, Undip, Jilid 40 No. 2 April 2011, hlm.222. Secara implisit hal ini bisa dilihat dalam ketentuan Pasal 2 PP Nomor 25 Tahun 2000 Tentang Kewenangan Pemerintah dan Kewenangan Propinsi Sebagai Daerah Otonom. 
frame hubungan pusat dan daerah tersebut, berdampak serius terhadap desain dan implementasi kebijakan pembangunan kawasan perbatasan. Di tingkat pusat misalnya, berdasarkan data dari Dirjend Pemerintahan Umum (PUM) Depdagri, ${ }^{5}$ setidaknya ada 24 instansi yang mengajukan anggaran APBN (Anggaran Pendapatan Belanja Negara) untuk pembangunan kawasan perbatasan dari berbagai perspektif. Kondisi serupa juga terjadi pada level birokrasi Pemerintah Daerah Provinsi Kalimantan Barat vis a vis Pemda Kabupaten yang di dalamnya banyak bersinggungan dengan berbagai dinas-yang sama-sama berkepentingan dengan kawasan perbatasan.

Melihat kompleksitas persoalan pengelolaan perbatasan tersebut-yang pada dasarnya berkutat pada masalah birokrasi yang egosentris, maka benang merah yang bisa disimpulkan adalah adanya keinginan kuat untuk merevitalisasi kawasan perbatasan agar bisa seimbang dengan kemajuan pembangunan di kawasan perbatasan negara tetangga. Namun sayangnya, dalam level tertentu semangat tersebut lebih dimotivasi oleh semangat kompetisi politis yang bersifat reaktif, terutama jika muncul kasus-kasus yang bersinggungan dengan Tenaga Kerja Indonesia (TKI) di Malaysia maupun persoalan demarkasi yang tidak kunjung usai. Padahal, selaras dengan prinsip-prinsip umum yang digariskan oleh PBB sebagaimana di atas maupun pilihan paradigm soft border regime yang dianut Indonesia, maka selayaknya pembangunan perbatasan tersebut memperhatikan kesalingterpengaruhan (interplay) diantara kedua sisi perbatasan, sehingga pendekatannya adalah kerjasama lintas batas. Dalam kaitan ini, Guo telah memberikan landasan teoritis yang strategis diaplikasikan, yakni Cross Border Approach (CBA).

CBA merupakan sebuah model pendekatan pembangunan perbatasan yang digagas oleh Roxing Guo. Dalam model ini, lebih mengutamakan pola kerjasama antar perbatasan untuk saling mengambil keuntungan dalam mengembangkan wilayah perbatasan di masing-masing negara. Pola kerjasama ini dapat dilaksanakan pada wilayah dengan karakteristik sebagai berikut. a) adanya perbedaan konsep pengembangan sosial ekonomi dengan wilayah tetangga; b) adanya keterbatasan jaringan penghubung, baik jalan maupun telekomunikasi di kota yang merupakan pusat kegiatan.

${ }^{5}$ Direktorat Jenderal Pemerintahan Umum-Departemen Dalam Negeri, "Perbatasan Antar Negara", Makalah dipresentasikan pada acara Seminar Nasional: Pengelolaan Wilayah Perbatasan Dalam Rangka Menjaga Keutuhan Negara Kesatuan Republik Indonesia, diselenggarakan oleh UPN Veteran, Yogyakarta, 18 November 2008.

${ }^{6}$ Guo, Border-Regional Economics. Heidelberg, Physica-Verl; Germany, 1996. hlm 118. 


\section{Rumusan Masalah}

Berdasarkan gambaran latar belakang masalah tersebut, maka dapat dirumuskan pertanyaan penelitian sebagai berikut. Pertama, faktor-faktor apa saja yang menyebabkan implementasi kebijakan pembangunan kawasan perbatasan belum bisa berjalan secara efektif? Kedua, apakah model Cross Border Approach sebagai alternatif kebijakan relevan diterapkan dalam pembangunan kawasan perbatasan, dan prasyarat apa saja yang dibutuhkannya?

\section{Tujuan Penelitian}

Penelitian ini secara khusus dimaksudkan untuk: Pertama, mengidentifikasi faktor-faktor apa saja yang menjadi akar permasalahan dari tidak lancarnya pelaksanaan kebijakan percepatan pembangunan kawasan perbatasan yang dihadapi oleh pemerintah selama ini; Kedua, menganalisis relevansi model Cross Border Approach sebagai alternatif model kebijakan percepatan pembangunan kawasan perbatasan dan persyaratan-persyaratan yang dibutuhkannya.

\section{Metode Penelitian}

Jenis penelitian ini adalah penelitian yuridis-normatif yang difokuskan pada pelaksanaan kebijakan. Dalam konteks ini, adalah pelaksanaan kebijakan pemerintah dalam pembangunan kawasan perbatasan dengan mengambil studi kasus di Kalimantan Barat yang berbatasan dengan Sarawak, Malaysia. Terkait dengan jenis penelitian ini, maka ada dua jenis data yang digunakan, yakni data primer yang digali dari lapangan dengan pihak yang bersinggungan secara langsung atau tidak langsung dengan penelitian ini. Selain itu, digunakan juga data sekunder yang terdiri dari dua jenis, yakni perundang-undangan dan hasil kajian sejenis baik di tingkat nasional maupun internasional. Teknik analisis data terhadap data primer dilakukan sejak peneliti berada di lapangan. Data yang telah diperoleh dianalisis dengan menggunakan analisis isi/kandungannya, dalam arti melihat makna yang mendalam dari setiap data yang telah dikumpulkan guna menjawab permasalahan penelitian ini. ${ }^{7}$

${ }^{7}$ Marzuki, P.M., Penelitian Hukum, Prenada Media, Jakarta, 2005 hlm.67; Ibrahim, J. Teori \& Metodologi Penelitian Hukum Normatif, Bayumedia, Malang, 2006 hlm.272; dan Moleong, J.L., Metodologi Penelitian Kualitatif, PT. Rosdakarya, Bandung, 2001. hlm.189. 


\section{Hasil Penelitian dan Pembahasan}

\section{Kebijakan Pembangunan Perbatasan}

Secara garis besar, fungsi-fungsi pelayanan, pendataan, pembangunan dan pemeliharaan kawasan perbatasan ke sisi dalam, yang meliputi aspek-aspek pembangunan politik, ekonomi, sosial, budaya, infrastruktur, lingkungan hidup, pertahanan dan keamanan dikerjakan dalam ruang lingkup atau tahapan ini. ${ }^{8}$

Berangkat dari kondisi obyektif tersebut, maka fungsi hukum sebagai alat rekayasa sosial dalam teori Roescoe Pound, ${ }^{9}$ dalam konteks perbatasan harus mampu mengawal perubahan paradigmatik negara terhadap perbatasan menjadi aksi konkrit menuju kesejahteraan. Terciptanya tujuan hukum sebagaimana dikehendaki oleh Roscoe Pound, dalam teori rekayasa sosial, lebih khusus adalah dalam kaitannya dengan upaya manusia dalam memenuhi kepuasan akan kebutuhan dan kemauan manusia. Lebih lanjut Roscoe Pound menegaskan, bahwa rekayasa sosial dalam kaitannya dengan pembangunan masyarakat melalui upaya mencapai tujuan hukum, yaitu suatu perubahan-perubahan yang terdiri dari pemikiran tidak sekedar dalam mengharmonisasikan kemauan manusia yang abstrak, akan tetapi pengamanan konkrit atau merealisasikan kepentingan manusia dalam wujud hasrat dan kepentingan kebendaan umat manusia.

Peranan kebijakan hukum tersebut dapat bermakna positif manakala upaya rekayasa sosial masyarakat dilandasi dengan semangat afirmasi dan nilai-nilai demokrasi. Dengan kata lain, kebijakan pembangunan kawasan perbatasan harus menjadi kemauan kuat pemerintah sebagai wujud tanggungjawabnya dalam melaksanakan kedaulatan negara di perbatasan. Sementara wujud demokrasinya, adalah memperhatikan aspirasi lokalitas perbatasan yang memiliki karakteristik yang khas dan strategis.

Kewajiban konstitusional negara yang dituangkan dalam UUD 1945 dengan gamblang tertera pada bagian pembukaannya, yang menyebutkan: “... melindungi segenap bangsa Indonesia dan seluruh tumpah darah Indonesia serta memajukan kesejahteraan

${ }^{8}$ Ibid., hlm. 15.

${ }^{9}$ Roscoe Pound merupakan salah satu pakar hukum terkemuka di Harvard Law School pada tahun 19161936 ketika dia menjadi Dekan. Ulasan mengenai teori Law As a Tool of Social Engineering dapat dibaca dalam Sai Abhipsa Gochhayat, Social Engineering By Roscoe Pound Issues In Legal and Politacal Philosophy, West Bengal National University Of Juridical Science, Kolkata http://ssrn.com/abstract=1742165, diakses tgl, 15 November 2010. 
umum.....", merupakan salah satu tujuan NKRI, yang jika dikristalisasikan salah satunya dalam bentuk kewajiban negara untuk merealisasikan pemenuhan hak masyarakatnya. Kegagalan negara/pemerintah dalam memenuhi kewajibannya dalam melindunggi dan memenuhi hak masyarakat tersebut akan melahirkan isu keadilan korektif sebagai justifikasi perlunya upaya hukum untuk menegakkan keadilan distributif. ${ }^{10}$

Dalam konteks pembangunan perbatasan, kebijakan keamanan yang selama ini menjadi pendekatan sentral, telah berdampak serius terhadap akses keadilan bagi masyarakat perbatasan dalam mendapatkan jatah pembangunan sosial-ekonomi yang setara dengan masyarakat di luar perbatasan. Namun, dalam perkembangan mutakhir Indonesia telah mengembangkan paradigma pengelolaan keamanan melalui pola pendekatan yang disebut dengan pendekatan komprehensif. Dalam pendekatan ini, berbagai faktor diintegrasikan seperti keamanan, kesejahteraan dan lingkungan. Diharapkan melalui kebijakan tersebut maka pengelolaan keamanan perbatasan bisa lebih baik, sehingga secara perlahan wajah perbatasan mengalami perubahan yang lebih baik pula. ${ }^{11}$ Secara praktis, perubahan paradigma dan pendekatan pembangunan perbatasan negara, khususnya di Kalimantan tersebut dapat dilacak melalui penelusuran kasus dan dinamika yang melingkupi hubungan kedua negara tersebut.

Pertama, pergesekan politik dengan Malaysia. Misalnya, dalam kasus SipadanLigitan yang berujung pada kekalahan Indonesia di Mahkamah Internasional pada 2002. Bermula dari kasus ini yang diiringi dengan rentetan kasus-kasus perbatasan lainnya yang bersifat hukum dan politis, seperti sengketa batas wilayah, patok perbatasan, illegal loging, illegal fishing dan lain sebagainya.

Berbagai fenomena tersebut memberikan inspirasi bagi pemerintah untuk secara serius mengelola perbatasan negara yang selama berpuluh tahun tidak pernah disentuh. Titik tolak (starting point) dari upaya tersebut dimulai pada 2007 lalu dengan disahkannya UU No. 27 Tahun 2007 tentang Pengelolaan Wilayah Pesisir dan PulauPulau Kecil. Semangat yang melandasi kelahiran undang-undang ini selain bernuansa ekonomi-maritim juga erat kaitannya dengan batas maritim negara dengan sejumlah

\footnotetext{
${ }^{10}$ Secara kmprehensif, diskursus mengenai keadilan dapat dibaca dalam Michael J. Sandel. Justice What's The Right Thing To Do?. Penguin Books, England, 2009. hlm.19-20.

${ }^{11}$ Lihat Sugeng Hadiwinata, 2009. "Dari Pendekatan Keamanan Menuju Pendekatan Komprehensif”, dalam Wuryandari, Keamanan di Perbatasan Indonesia-Timor Leste: Sumber Ancaman dan Kebijakan Pengelolaannya, Pustaka Pelajar dan P2P LIPI, Yogyakarta, 2009, hlm. 319.
} 
negara tetangga. Undang-undang ini kemudian ditindaklanjuti dengan Keputusan Menteri Kelautan Dan Perikanan Nomor: Kep. 10/Men/2002 tentang Pedoman Umum Perencanaan Pengelolaan Pesisir Terpadu, Tanggal 9 April 2002.

Setahun berikutnya, disahkan UU No. 43 Tahun 2008 tentang Wilayah Negara. Melengkapi kedua instrumen hukum tersebut, pemerintah melalui Peraturan Presiden No.12 Tahun 2010 membentuk Badan Nasional Pengelola Perbatasan, yang secara teknis dilengkapi dengan Permendagri No. 2 Tahun 2012 tentang Pedoman Pembentukan Badan Pengelola Perbatasan di Daerah.

Jika dilihat dari perspektif Hukum Internasional, kesadaran terhadap kawasan perbatasan negara tersebut terbilang cukup terlambat. Sebab, pada 1982, Indonesia melalui perjuangan Deklarasi Djuanda yang berujung manis dengan disahkannya UNCLOS 1982 oleh PBB, telah memberikan banyak keuntungan bagi Indonesia sebagai negara kepulauan (Archipelagic State). Semestinya, kedua undang-undang "perbatasan negara" tersebut dilahirkan tidak terlalu jauh dari UNCLOS 1982, sehingga konsentrasi berikutnya lebih fokus pada sisi pengelolaan wilayah perbatasan $^{12}$.

Kedua, peristiwa lainnya yang menggugah kesadaran atas pengelolaan wilayah perbatasan Negara tersebut, secara historis berasal dari gagasan pemimpin negara tetangga, yakni Dato' Musa Hitam dalam sebuah kesempatan sidang perbatasan di Kuala Lumpur pada 1983, yang melontarkan gagasan untuk membangun jalinan kerjasama pembangunan perbatasan-yang kemudian hari dikenal dengan sebutan kerjasama sosial-ekonomi Malaysia-Indonesia (Sosek Malindo). ${ }^{13}$

Berangkat dari gagasan itulah kemudian Indonesia mulai memberikan perhatian terhadap pembangunan kawasan perbatasan dari sisi sosial dan ekonominya. Sebelum itu, kebijakan terhadap perbatasan didominasi oleh isu-isu pertahanan dan keamanan yang menyebabkan kawasan perbatasan menjadi kawasan terisolir (isolated) dan berbahaya. Kondisi ini secara sadar telah menegasikan eksistensi penduduk yang ada di kawasan tersebut, sehingga hak-haknya secara konstitusional untuk mendapatkan pembangunan guna meningkatkan taraf kehidupan mereka-yang

${ }^{12}$ Diskursus mengenai dinamika perbatasan laut dan pengelolaanya dapat dibaca dalam Cribb dan Ford, Indonesia Byond The Water's Edge: Managing an Archipelagic State. Institute of Southeast Asian Studies, Singapore, 2009. hlm.3.

${ }^{13}$ Irwan Lahnisafitra, "Pentingnya Kerjasama Sosial Ekonomi Malaysia - Indonesia (Sosek Malindo) dan Kaitannya dengan Pertumbuhan Sub Regional ASEAN (Studi Kasus : Kerjasama Sosek Malindo Tingkat Daerah Kalbar - Sarawak)", Makalah dipresentasikan dalam kegiatan Seminar Internasional Indonesia-Malaysia Update, UGM Yogyakarta, 27 - 29 Mei 2008, hlm.13. 
sejajar dengan kawasan lainnya menjadi terabaikan. Berbarengan dengan itu, sudut pandang pemerintah terhadap negara adalah sebagai kawasan belakang negara.

Berdasarkan Undang-Undang No. 25 Tahun 2000 tentang Program Pembangunan Nasional (Propenas) juga telah dijelaskan bahwa dalam pengembangan wilayah perbatasan perlu diprioritaskan dan mendapat perlakuan khusus dalam rangka peningkatan taraf hidup, kesejahteraan masyarakat, serta mengokohkan ketertiban dan keamanan daerah yang berbatasan dengan negara lain. Program prioritas ini dijabarkan lagi dalam Rencana Pembangunan Tahunan (Repeta) yang disusun setiap tahun dan bertujuan untuk menjaga keutuhan wilayah Negara Kesatuan Republik Indonesia (NKRI) dan menjadikan wilayah perbatasan sebagai beranda depan negara melalui delimitasi dan demarkasi batas, pengamanan wilayah perbatasan dan pembangunan sosial ekonomi wilayah sepanjang perbatasan.

Dalam Rencana pembangunan tahunan wilayah perbatasan 2004 misalnya dijabarkan dalam 3 (tiga) kelompok kegiatan, yaitu kelompok kegiatan penetapan garis batas internasional, kelompok kegiatan pengamanan wilayah perbatasan dan kelompok kegiatan pengembangan wilayah perbatasan. Kemudian, berdasarkan RPJMN 2004-2009 disebutkan bahwa pembangunan kawasan perbatasan menjadi beranda depan negara. Program ini ditujukan untuk: (1). menjaga keutuhan wilayah NKRI melalui penetapan hak kedaulatan NKRI yang dijamin oleh hukum internasional; (2). meningkatkan kesejahteraan masyarakat setempat dengan menggali potensi ekonomi, sosial dan budaya, serta keuntungan lokasi geografis yang sangat strategis untuk berhubungan dengan negara tetangga. Selanjutnya, arah kebijakan pembangunan kawasan perbatasan 2010-2014 adalah: “Mempercepat pengembangan kawasan perbatasan sebagai beranda depan negara sekaligus pintu gerbang aktivitas ekonomi dan perdagangan dengan negara tetangga secara terintegrasi dalam rangka peningkatan kesejahteraan masyarakat dan keamanan negara dengan memperhatikan kelestarian lingkungan hidup"14.

Karakteristik berbagai perundang-undangan yang terkait dengan perbatasan, memiliki keterkaitan erat dengan upaya percepatan penyelesaian batas wilayah negara, serta mencerminkan adanya pergeseran paradigma dan arah kebijakan pembangunan kawasan perbatasan dari yang selama ini cenderung berorientasi "inward looking", menjadi "outward looking" sebagai pintu gerbang aktivitas ekonomi

\footnotetext{
${ }^{14}$ Badan Nasional Pengelola Perbatasan (BNPP) Republik Indonesia, 2011. Desain Besar (Grand Design) Pengelolaan Batas Wilayah Negara Dan Kawasan Perbatasan Tabun 2011-2025, SERI BNPP 01S-0111, Jakarta, hlm.9.
} 
dan perdagangan dengan negara tetangga. Di samping itu, pendekatan pengelolaan perbatasan negara pun, tampak mengalami pergeseran dengan mengedepankan kombinasi pendekatan kesejahteraan (prosperity approach) yang dilaksanakan secara serasi dengan pendekatan keamanan (security approach) dan pendekatan lingkungan (environment approach) ${ }^{15}$.

Sesuai dengan ketentuan Permendagri No.12 Tahun 2010 tentang Badan Nasional Pengelola Perbatasan (BNPP), maka terkait dengan pembangunan kawasan perbatasan, kewenangan penyusunan dan koordinasi program perbatasan berada di bawah naungan Deputi Bidang Pengelolaan Potensi Kawasan Perbatasan dan Deputi Bidang Pengelolaan Infrastruktur Kawasan Perbatasan.

Dalam ketentuan Pasal 11 ayat (3) dan ayat (4) dinyatakan: ayat (3), Deputi Bidang Pengelolaan Potensi Kawasan Perbatasan mempunyai tugas: (a). melakukan penyusunan dan perumusan rencana induk dan rencana aksi serta pengoordinasian penyusunan kebijakan dan pelaksanaan pembangunan, pengelolaan, dan pemanfaatan potensi Kawasan Perbatasan; (b). melakukan inventarisasi potensi sumber daya dan membuat rekomendasi penetapan zona pengembangan ekonomi, pertahanan, sosial budaya, lingkungan hidup dan zona lainnya di Kawasan Perbatasan; (c). mengoordinasikan penyusunan anggaran pembangunan dan pengelolaan potensi Kawasan Perbatasan sesuai dengan skala prioritas; (d). melakukan pengendalian, pengawasan, evaluasi dan pelaporan pelaksanaan pembangunan serta pengelolaan Potensi Kawasan Perbatasan.

Beberapa kewenangan yang dimiliki oleh kedua Deputi pengelolaan kawasan tersebut dalam perspektif perencanaan lebih berfungsi sebagai perencana yang hasilnya dijadikan sebagai blue print kebijakan program bagi lembaga teknis yang terkait. Namun demikian, terdapat sedikit keganjilan pada butir (d) baik di ayat (3) maupun ayat (4) yang memberikan kewenangan pelaporan di samping pengendalian dan pengawasan. Sebab, logika pelaporan adalah dilakukan jika instansi tersebut memiliki kewenangan untuk melaksanakan program-program yang dibuatnya tersebut. Padahal, pelaksanaan riil dari hasil rekomendasi program kegiatan yang dilakukan oleh badan pengelola perbatasan adalah instansi terkait.

Secara faktual pada 2012, program pembangunan perbatasan di tingkat lokal, berdasarkan daftar isian anggaran yang dikeluarkan oleh Bappeda Kalimantan Barat

${ }^{15}$ Pasal 7 Peraturan Badan Nasional Pengelola Perbatasan Tentang Desain Besar Pengelolaan Batas Wilayah Negara dan Kawasan Perbatasan Tahun 2011-2025. 
terlihat sangat padat. Program-program tersebut dilakukan oleh 2 (instansi), yakni satu instansi teknis dalam hal ini Dinas Prasarana Umum (PU) Kalimantan Barat, satu instansi lainnya adalah badan pengelola perbatasan, yakni: Badan Pengelola Kawasan Perbatasan dan Kerjasama (BPKPK) Provinsi Kalimantan Barat; BPKPK Unit Pengelola PPLB Entikong; BPKPK Unit Pengelola Aruk; dan BPKPK Unit Pengelola Badau.Secara umum program-program kegiatan yang dianggarkan dalam APBD Provinsi Kalimantan Barat tersebut cukup kompleks, dari infrastruktur sampai dengan evaluasi program.

\section{Kendala-Kendala Implementasi Kebijakan}

Berbagai kendala implementasi kebijakan pembangunan kawasan perbatasan, khususnya di Kalimantan Barat adalah disebabkan oleh beberapa hal sebagai berikut: Pertama, faktor ego sektoral. Pada awalnya sebelum pembentukan Badan Pengelola Perbatasan sebagaimana yang diperintahkan dalam UU No. 43 Tahun 2008 tentang Wilayah Negara, sedikitnya terdapat 24 instansi yang mengajukan anggaran ke Pemerintah untuk pembangunan kawasan perbatasan. Jika dilihat dari perspektif yuridis-formal, maka hal itu dapat dimaknai positif, dalam arti bahwa pemerintah beserta jajarannya memiliki kepedulian yang tinggi terhadap pembangunan perbatasan. Namun sayangnya, dibalik itu semua motif yang muncul adalah proyek. Hal ini diyakini oleh Manto selaku Kepala UPT Aruk Sajingan Besar. ${ }^{16}$ Hanya saja istilah proyek menurut Manto lebih diperhalus lagi menjadi program.

Menurut Manto sudah menjadi kultur birokrasi di berbagai level pemerintahan, bahwa setiap instansi akan berupaya memperjuangkan program-programnya untuk kepentingan instansinya, dan sangat sulit untuk bisa dilepaskan atau dibagi dengan instansi lainnya. Bahkan, ketika BNPP terbentuk menurut Baihaqi dari Dirjend PUM dan juga Bambang W dari BNPP ${ }^{17}$ situasi tersebut berlanjut dalam politik penganggaran untuk perbatasan. Proporsi anggaran diibaratkan kue yang dibagibagikan ke dalam berbagai instansi teknis tanpa memikirkan subtansi kebutuhan di riil di lapangan. Kondisi ini menegaskan bahwa program pembangunan perbatasan tidak direncanakan secara matang, dan sekali lagi mengesankan kuatnya nuansa proyek. Kedua, lemahnya wewenang Badan Pengelola Perbatasan. Kehadiran Undang-Undang Nomor 43 Tahun 2008 tentang Wilayah Negara diharapkan menjadi

\footnotetext{
${ }^{16}$ Wawancara, 5/11/2012.

${ }^{17}$ Wawancara secara terpisah, 7/12/2012.
} 
payung hukum pemerintah pusat dan daerah untuk betul-betul punya komitmen yang tinggi dalam upaya akselerasi pembangunan kawasan perbatasan. Di dalam Pasal 9 UU No. 43 Tahun 2008 ditegaskan bahwa Pemerintah dan Pemerintah Daerah berwenang mengatur pengelolaan dan pemanfaatan Wilayah Negara dan Kawasan Perbatasan.

Sebelum adanya BNPP tersebut, setidaknya ada 60-an program yang secara langsung atau tidak langsung berkaitan dengan kepentingan kemajuan perbatasan. Program ini tersebar secara sektoral di 29 Kementerian/Lembaga pemerintah non kementerian dan tidak memiliki keterkaitan yang jelas dalam sebuah koordinasi yang mantap, sehingga hasilnya pun tidak menunjukkan kemajuan yang signifikan di perbatasan. Ketertinggalan, keterisolasian, keterbelakangan, kemiskinan, dan predikat lain yang menunjukkan kekurang berhasilan penanganan perbatasan, merupakan sebuah fakta dan isu strategis manajemen perbatasan, sehingga mendesak direspon dengan pembentukan BNPP sebagai badan pengelola yang salah satu fungsinya melakukan koordinasi pengelolaan perbatasan.

Berbagai tugas pokok dan fungsi tersebut saat ini dalam prakteknya, seperti disampaikan oleh Manto Kepala UPT PPLB Aruk Sajingan Besar, Sambas ${ }^{18}$, tetap menunjukkan parsialitas dan tidak sinergi. Posisi Badan Pengelola sendiri, tidak ubahnya hanya sebatas event organizer yang memfasilitasi kegiatan-kegiatan seremonial. Jika dilihat dalam Pasal 15 ayat (2) UU No. 43 Tahun 2008 tentang Wilayah Negara, kondisi ini dengan jelas "mendapatkan legitimasi dari undang-undang tersebut. Dalam ketentuan Pasal 15 ayat (2) tersebut dinyatakan, bahwa Pelaksana teknis pembangunan dilakukan oleh instansi teknis sesuai dengan tugas pokok dan fungsinya. Dalam konteks ini, pemaknaan terhadap kalimat "dilakukan oleh instansi teknis sesuai dengan tupoksinya", secara eksplisit dipahami secara sempit. Dalam arti tidak ada perubahan, semua anggaran dan SDM dalam pembangunan perbatasan masih dilakukan secara parsial. Lain halnya, jika hal itu secara eksplisit ditegaskan bahwa pelaksanaan pembangunan kawasan perbatasan dilakukan oleh Badan Pengelola sebagai leading sector-nya, maka sinergi dan kebersamaan dapat dilakukan secara efektif.

Ketiga, inkonsistensi kebijakan teknis dengan paradigma perbatasan. Perubahan paradigmatik terhadap sudut pandang perbatasan dari beranda belakang menjadi beranda depan negara, menunjukkan sebuah komitmen yang kuat dari stakeholders

\footnotetext{
${ }^{18}$ Wawancara,5/11/2012.
} 
untuk merubah secara revolusioner pembangunan kawasan perbatasan yang memiliki nilai strategis dalam penegasan kedaulatan negara. Oleh sebab itu, perspektif tersebut kemudian mendorong semangat membangun perbatasan untuk mengejar ketertinggalannya dengan kawasan perbatasan negara tetangga yang telah berkembang lebih jauh.

Perubahan paradigmatik tersebut kemudian pada tataran teknis diterjemahkan oleh pemerintah dengan merancang program pembangunan yang menjadikan Tata Ruang sebagai entry point-nya. Oleh karena itu, Rencana Tata Ruang Wilayah Nasiona (RTRWN) disusun dengan memperhatikan dinamika pembangunan yang berkembang, antara lain: tantangan globalisasi, otonomi dan aspirasi daerah, keseimbangan perkembangan antara Kawasan Barat Indonesia dengan Kawasan Timur Indonesia, kondisi fisik wilayah Negara Kesatuan Republik Indonesia yang rentan terhadap bencana, dampak pemanasan global, pengembangan potensi kelautan dan pesisir, pemanfaatan ruang kota pantai, penanganan kawasan perbatasan negara, dan peran teknologi dalam memanfaatkan ruang.

Dalam konteks itu, UU No. 26 Tahun 2007 tentang Penataan Ruang, khususnya Pasal 5 ayat (5) menjadikan kawasan perbatasan sebagai Kawasan Strategis Nasional, yakni kawasan yang di dalamnya berlangsung kegiatan yang mempunyai pengaruh besar terhadap: (a). tata ruang di wilayah sekitarnya; (b). kegiatan lain di bidang yang sejenis dan kegiatan di bidang lainnya; dan/atau (c). peningkatan kesejahteraan masyarakat.

Selanjutnya Pasal 1 butir (22) PP No. 26 Tahun 2008 tentang Rencana Tata Ruang Wilayah Nasional mendefinisikan Pusat Kegiatan Strategis Nasional (PKSN) sebagai kawasan perkotaan yang ditetapkan untuk mendorong pengembangan kawasan perbatasan negara. Ketentuan ini diperjelas kembali dalam Pasal 13 ayat (1) yang menyatakan: Selain sistem perkotaan nasional sebagaimana dimaksud dalam Pasal 11 ayat (1) dikembangkan PKSN untuk mendorong perkembangan kawasan perbatasan negara. Dalam penjelasan Pasal 13 ayat (1) dinyatakan: yang dimaksud dengan "kawasan perbatasan negara" adalah wilayah kabupaten/kota yang secara geografis dan demografis berbatasan langsung dengan negara tetangga dan/atau laut lepas. Kawasan perbatasan negara meliputi kawasan perbatasan darat dan kawasan perbatasan laut termasuk pulau-pulau kecil terluar. Pengembangan PKSN dimaksudkan untuk menyediakan pelayanan yang dibutuhkan untuk mengembangkan kegiatan masyarakat di kawasan perbatasan, termasuk pelayanan kegiatan lintas batas antarnegara. 
Dalam konteks itu, maka diperlukan kelembagaan yang spesifik juga, agar prioritas-prioritas pembangunan dan penanganan masalah yang ada bisa berjalan dengan cepat dan responsif. Namun sayangnya,kenyataan di lapangan kebijakan teknis yang dibuat justru tidak konsisten dengan paradigma penanganan perbatasan dan kebijakan peruntukan kawasan perbatasan sebagai kawasan strategis nasional yang memerlukan prioritas penanganan dalam pendataannya. Hal itu setidaknya diindikasikan oleh tiga kebijakan teknis yang tidak konsisten dengan paradigma dan fungsi kawasan tersebut.

Pertama, kelembagaan yang tidak kuat. Hal ini diindikasikan oleh kewenangan yang dimiliki oleh BNPP di tingkat pusat maupun Badan Pengelola Perbatasan di tingkat daerah yang hanya berfungsi sebagai koordinator. Direktorat Jenderal Pemerintahan Umum, sebagaimana disampaikan oleh Ismintarti maupun Baihaqi ${ }^{19}$ mengistilahkannya sebagai "Bappenas"-nya Perbatasan.

Wewenang koordinatif tersebut, menurut Manto, ${ }^{20}$ dalam implementasinya cukup sulit dilaksanakan. Sebab, menurutnya 18 (delapan belas) kementerian/LNPK dan 12 Provinsi yang menjadi bagian dari struktur kelembagaan BNPP di tingkat pusat maupun dinas-dinas di tingkat daerah, dalam kenyataannya ketika diundang oleh BNPP mereka merasa bukan orang BNPP. Kondisi yang sama juga dirasakan di tingkat daerah. Hal ini juga diperkuat dengan masih berjalannya model penganggaran melalui mekanisme Musrenbang, sehingga pola penganggaran pembangunan perbatasan masih parsial.

Kedua, fungsi kecamatan yang tidak diprioritaskan. Sesuai dengan UU No. 43 Tahun 2008 tentang Wilayah Negara, kawasan perbatasan adalah bagian dari wilayah negara yang terletak pada sisi dalam sepanjang batas wilayah Indonesia dengan negara lain, dalam hal batas wilayah negara di darat, kawasan perbatasan berada di kecamatan. Hasil identifikasi 2010, terdapat 197 kecamatan yang berada pada kawasan perbatasan negara. Sesuai dengan PP No. 26 Tahun 2008 tentang RTRWN, kawasan perbatasan secara keseluruhan mencakup 10 cluster/kawasan, terdiri dari 3 kawasan perbatasan darat, dan 7 kawasan perbatasan laut. Cakupan Wilayah Administrasi Provinsi (CWAP) yang termasuk ke dalam kawasan perbatasan secara keseluruhan meliputi 21 provinsi.

\footnotetext{
${ }^{19}$ Wawancara, 7/11/2012.

${ }^{20}$ Wawancara, 5/11/2012.
} 
Menurut Intan Kumala Putri, ${ }^{21}$ pada era UU No. 5 Tahun 1974, kecamatan pernah memiliki posisi sangat kuat dengan peran dan fungsi kecamatan yang melekat pada camat sebagai Unit Daerah Kerja Pembangunan (UDKP). Pada masa itu, terdapat 3 (tiga) fungsi klasik yang dijalankan oleh kecamatan selama ini, yaitu fungsi pemerintahan termasuk dalam konteks ini adalah pelayanan publik, pembangunan, dan kemasyarakatan (menyelesaikan persoalan masyarakat di ruang sipil). Fungsi ini terus melekat, sekalipun terjadi perubahan rezim dari sentralistik ke desentralistik.

Dalam UU Nomor 32 Tahun 2004 tersebut dinyatakan, bahwa kecamatan tidak lagi merupakan satuan wilayah kekuasaan pemerintahan, melainkan sebagai satuan wilayah kerja atau pelayanan. Dengan demikian, status kecamatan kini merupakan perangkat daerah kabupaten/kota yang setara dengan lembaga teknis daerah, bahkan setara dengan kelurahan. Hal ini dengan jelas dinyatakan dalam Pasal 120 ayat (2) UU Nomor 32 Tahun 2004 yang menyebutkan: "Perangkat daerah Kabupaten/Kota terdiri atas sekretariat daerah, sekretariat DPRD, dinas daerah, lembaga teknis daerah, kecamatan, dan kelurahan". Selain itu, camat tidak lagi ditempatkan sebagai kepala wilayah dan wakil pemerintah pusat, seperti dalam UU Nomor 5 Tahun 1974, melainkan sebagai perangkat daerah. Camat merupakan kepanjangan tangan (alter ego). Realitas ini menunjukkan, bahwa camat secara hukum telah mengalami perubahan status dan kewenangan yang sangat siginifikan. Kondisi ini dalam konteks wilayah perbatasan, berdampak negatif dalam pelayanan publik.

Ketiga, kebijakan penganggaran tidak berbasis kebutuhan. Parsialitas dalam sistem penganggaran pembangunan kawasan perbatasan merupakan konsekuensi langsung dari budaya sektoralitas dalam pembangunan perbatasan. Meskipun kondisi ini telah dijembatani dengan pembentukan Badan Nasional Pengelola Perbatasan (BNPP), namun kenyataannya masih berjalan secara parsial. Jika pada 2012 anggaran pembangunan perbatasan mencapai Rp. 3.850.000.000.000,00, yang kenyataannya tidak bisa dicairkan secara keseluruhan dan sebagiannya lagi banyak digunakan untuk biaya proses dan sisanya saja yang dijalankan untuk pembangunan perbatasan. $^{22}$

Kondisi tersebut diperparah lagi dengan model penganggaran yang dibuat tidak berbasis pada kebutuhan riil, melainkan penjatahan dari Dirjen Anggaran. Baihaqi, ${ }^{23}$

${ }^{21}$ Putri, E.I.K., Refungsionalisasi Kecamatan dalam Perencanaan Pembangunan Wilayah Spasial, Project Working Paper Series No.04, Pusat Studi Pembangunan Pertanian dan Perdesaan, IPB, 2008. hlm.4.

22 Manto, Wawancara, 5/11/2012.

${ }^{23}$ Wawancara, 7/11/2012. 
menjelaskan bahwa model penganggaran pembangunan perbatasan diibaratkan pembagian kue ulang tahun yang diiris dan dibagi-bagi pada sejumlah kementerian. Hal ini mengindikasikan bahwa, kebijakan penganggaran pembangunan perbatasan tidak disiapkan dengan serius, bahkan terkesan hanya "proyek", meskipun istilah ini menurut Manto, ${ }^{24}$ diperhalus lagi dengan istilah pekerjaan. Padahal untuk membangun kawasan perbatasan yang selama berpuluh tahun terbengkalai perlu dana banyak.

Sementara itu, menurut Baihaqi dari Dirjen $\mathrm{PUM}^{25}$ dan Manto dari BPKPK Provinsi Kalbar, ${ }^{26}$ model penganggaran untuk pembangunan kawasan perbatasan, diibaratkan pembagian kue ulang tahun kepada kementerian yang mengajukan anggaran. Dalam konteks itu, penganggaran dari masing-masing kementerian telah dijatah dengan tanpa memperhatikan subtansi kebutuhan dari penganggaran tersebut. Padahal dalam model penganggaran yang digagas oleh Kementerian Keuangan menggunakan prinsip money follow function. Prinsip money follows function, yang mengandung makna bahwa pendanaan mengikuti fungsi pemerintahan. ${ }^{27}$

\section{Potensi Kerjasama Lintas Batas}

Kerjasama lintas batas antara Indonesia dengan Malaysia khususnya di Kalimantan Barat-Sarawak yang dikenal paling progresif dalam kerjasama Sosek Malindo, secara embrional dapat ditingkatkan menjadi model alternatif kebijakan pembangunan kawasan perbatasan. Pendekatan kebijakan ini penting diperkuat, sebab akan berimplikasi pada seluruh proses pembangunan kawasan perbatasan. Berdasarkan data dan analisis yang dilakukan oleh tim peneliti, maka terdapat sejumlah kelebihan dari model Sosek Malindo tersebut sebagai model Cross Border Approach dalam pembangunan perbatasan, seperti: adanya keuntungan bersama dari kedua belah pihak, program-program kerjasama yang digagas digali dari kebutuhan riil di lapangan, dan program tersebut dalam konteks Indonesia dilaksanakan secara responsif dan menegaskan ego sektoral yang selama ini menjadi beban persoalan utama dalam pengelolaan kawasan perbatasan. Deskripsi mengenai beberapa keuntungan model Sosek Malindo sebagai embrio model Cross Border Approach tersebut adalah sebagai berikut.

${ }^{24}$ Wawancara, 5/11/2012.

${ }^{25}$ Wawancara, 7/11/2012.

${ }^{26}$ Wawancara, 5/11/2012.

27 Kemenkeu, Money Follow Function dalam Penganggaran Berbasis Kinerja, dalam < http:// www.anggaran.depkeu.go.id/web-content-list.asp?ContentId=247> diakses tanggal 9 Desember 2012. 
Pertama, Mutual Benefit (Saling Menguntungkan). Secara faktual adanya keterkaitan antar kedua sisi perbatasan baik dari aspek fisik, sosial, ekonomi dan budaya, maka hal itu dapat memberikan dampak positif bagi kedua belah pihak. Masyarakat perbatasan Kalimantan Barat, pada umumnya memiliki sumber daya alam dan manusia yang memadai, tetapi tidak memiliki alat-alat produksi sehingga memasarkan sumber daya alam yang dimiliki ke daerah Sarawak. Sebaliknya, masyarakat di Sarawak memiliki barang-barang produksi yang dapat dijual ke masyarakat Perbatasan Kalimantan Barat.

Secara normatif hal itu dipayungi dengan berbagai kebijakan regulasi seperti Border Trade Agreement (1970) dan kesepakatan aksesibilitas bagi masyarakat perbatasan sejauh kota-kota terdekat $( \pm 5 \mathrm{~km})$. Kemudahan-kemudahan tersebut menunjukkan bahwa hubungan kedua negara dalam konteks perbatasan adalah hubungan harmoni dan saling menguntungkan.

Sebagai perbandingan, kelebihan soft border regime yang diterapkan oleh Pemerintah kedua negara di wilayah perbatasan (Indonesia-Malaysia), pada aspekaspek tertentu memiliki kesamaan dengan perbatasan negara-negara di kawasan Uni Eropa. Association of European Border Region ${ }^{28}$ dalam deklarasi tahunannya menyebutkan, bahwa penduduk yang tinggal di kawasan perbatasan dapat saling membangun kerjasama dalam mempromosikan perdamaian, kebebasan, keamanan dan HAM. Secara spesifik dalam deklarasi tersebut diuraikan bentuk-bentuk keuntungan yang didapatkan oleh masyarakat perbatasan Uni Eropa tersebut, misalnya dalam aspek politik dan organisasi.

Dalam aspek politik, keuntungan yang didapatkan dari kehidupan bertetangga secara damai tersebut adalah: pembangunan Eropa secara umum dan integrasi Eropa secara keseluruhan; saling mengetahui satu sama lain, saling memahami, saling bekerjasama, dan membangun saling kepercayaan, mempersiapkan akses keanggoataan baru (agar bisa dipahami dan diterima oleh masyarakat perbatasan), penggunaan dana Uni Eropa untuk mengamankan kerjasama lintas batas melalui berbagai program tahunan, baik untuk kontek nasional maupun regional. Sementara dalam konteks kelembagaan, keuntungan yang didapat adalah: pelibatan stakeholders dalam berbagai kegiatan kerjasama perbatasan, baik secara ekonomi maupun kegiatan-kegiatan pembangunan infrastruktur dan sosial kemasyarakatan.

${ }^{28}$ Association of European Border Region, Contribution of Cross-Border Co-Operation to Implementing The Lisbon Strategy, AEBR Annual Conference, 20-21 October 2005 In Drama, Euroregion Nestos-Mesta. hlm.3. 
Dalam perspektif tersebut, maka selayaknya semangat paradigmatik yang dibangun dalam perencanaan pembangunan kawasan perbatasan adalah cooperative bukan competitive. Dalam model cooperative, yang terjadi adalah adanya hubungan interplay-mutualistic yang saling menguntungkan. Hanya saja dalam konteks ini diperlukan dialog dan saling kesepahaman bersama yang dituangkan dalam kerjasama lintas batas, sehingga satu sama lain bisa saling memahami kebutuhannya masing-masing. Sementara jika model competitive, maka akan menghasilkan pergesekan negatif dari kedua belah pihak, sehingga tidak tercipta harmoni maupun saling kepercayaan diantara kedua belah pihak. Dengan demikian, maka berbagai program yang dibuat akan bersifat reaktif-emosional.

Kedua, Program Kerjasama Berbasis Kebutuhan. Pilihan model sidang kerjasama bilateral Sosek Malindo yang bersifat tahunan (annual) sebagaimana diuraikan pada bagian sebelumnya, membawa konsekuensi pada dua hal. Pertama, kedua belah pihak dituntut untuk menegosiasikan program-program kerjasama yang yang secara faktual dibutuhkan dan saling membawa manfaat bagi kedua belah pihak. Dalam ketentuan Misi Sosek Malindo disebutkan bahwa kedua belah pihak sama-sama memiliki misi untuk: mewujudkan peluang sosial-ekonomi dan budaya yang kondusif bagi kesejahteraan masing-masing yang bersepadanan; meningkatkan kerjasama ekonomi yang adil dan saling menguntungkan kedua belah pihak dengan terus mengutamakan pemeliharaan alam sekitar; dan meningkatkan kerjasama sosial dan budaya dalam meningkatkan kualitas sumber daya manusia di kedua negara/ daerah yang bersempadan.

Secara teknis, berbagai kesepakatan sidang Sosek Malindo tersebut diinternal Indonesia, baik menurut Baihaqi dari Dirjend PUM maupun Manto dari UPT PPLB Aruk Sambas ${ }^{29}$ direspon dan dilaksanakan secara teknis oleh semua dinas atau instansi teknis terkait. Berbagai program yang disepakati tersebut meskipun tidak berupa kontrak perjanjian baku, maka atas nama citra baik negara harus dilakukan dengan segera dan hasilnya akan dievaluasi pada sidang Sosek tahun berikutnya.

Ketiga, Program Dilaksanakan Secara Responsif. Berbeda dengan model program kerja yang secara konvensional disusun oleh Pemerintah dengan model Musyawarah Rencana Pembangunan (Musrenbang) yang keputusan akhirnya ada di Pemerintah Pusat, maka dalam model Sosek Malindo masing-maisng pihak mengajukan program kerja yang didasarkan atas hasil kesepakatan bersama. Terhadap kesepakatan-

\footnotetext{
${ }^{29}$ Wawancara, 5 dan 7/11/2012.
} 
kesepakatan tersebut, maka pemerintah Indonesia secara responsif di bawah pengawasan Badan Pengelola Perbatasan (BPKPK atau BNPP) menindaklanjutinya sampai benar-benar terealisir, sehingga pada pertemuan Sosek Malindo pada tahun berikutnya kemajuan tersebut dapat dilaporkan dan dievaluasi perkembangannya. Jika sudah berjalan dengan baik, maka menurut Manto ${ }^{30}$ tidak dibahas lagi, dan jika belum berjalan sebagaimana disepakati maka akan dibahas lagi.

Prescott dan Triggs, ${ }^{31}$ mengaitkan kondisi perbatasan yang harmonis tersebut sebagai konsekuensi dari strategisnya geografi perbatasan, sehingga pada dekade 1920-an di Jerman hal itu melahirkan sebuah disiplin baru dalam ilmu geografi yang disebut dengan geopolitik. Pengertian dari disiplin ilmu ini adalah peran dari geografi terhadap pembentukan kebijakan negara. Dalam konteks perbatasan, bisa dimaknai sebagai hubungan saling keterpengaruhan (interplay) karena adanya keterkaitan di berbagai bidang, terutama secara fisik (daratan), sehingga mendatangkan keuntungan ekonomi. $^{32}$

Vitalitas geografi (darat) dalam konteks relasi perbatasan dalam banyak kasus bisa berujung pada munculnya konflik, manakala kebijakan politik dalam hubungan kedua negara bertetangga tidak baik. Kondisi demikian akan melahirkan kebijakan penanganan perbatasan menggunakan pendekatan rezim hard border yang menempatkan militer sebagai kekuatan utama. Sebaliknya, jika terjadi kedamaian dan keharmonisan sebagaimana dalam hubungan Kalbar-Sarawak, maka hal itu dapat melahirkan rezim soft border yang memperkuat hubungan sosial dan ekonomi di kawasan perbatasan. Sebaliknya, kekuatan militer dikonsentrasikan untuk mengamankan aktivitas tersebut. ${ }^{33}$ Dengan demikian, hubungan kedua negara bertetangga dapat berjalan dengan damai dan harmoni.

\section{Penutup}

Berdasarkan hasil analisis data penelitian ini, maka dapat disimpulkan, pertama, faktor-faktor yang menyebabkan model kebijakan pembangunan yang digunakan pemerintah kurang relevan dengan karakteristik kawasan diantaranya, kultur birokrasi yang masih sektoral, lemahnya wewenang badan pengelola perbatasan,

\footnotetext{
${ }^{30}$ Wawancara, 5/11/2012.

${ }^{31}$ Prescott, V. dan Triggs, G.D., International Frontiers and Boundaries: Law, Politics and Geography, Martinus Nijhoff Publisher, Leiden, 2008, hlm.7.

${ }^{32}$ Lihat Roxing Guo, Border-Regional Economics....Op.Cit. hlm.6.

${ }^{33}$ Wuryandari, Keamanan di Wilayah Perbatasan..... Op.Cit.
} 
inkonsistensi kebijakan teknis dengan paradigma pembangunan perbatasan, serta faktor kondisi geografis yang terisolir memerlukan penanganan yang extra-ordinary. Kedua, model pendekatan kerjasama lintas batas (Cross Border Approach), yang secara embrional diwujudkan dengan adanya Kerjasama Sosek Malindo sejak 1983, dapat menjadi alternatif model kebijakan pembangunan perbatasan, di tengah model kebijakan konvensional yang ada. Hal ini ditunjukkan melalui beberapa kelebihan yang dimiliki oleh model Sosek Malindo tersebut, antara lain: program kerjasama yang digagas bersifat mutual benefit (saling menguntungkan) bagi kedua pihak yang berbatasan. Dengan karakteristik wilayah perbatasan yang saling terpengaruh (interplay) sebagaimana diuraikan di atas, maka antar kedua sisi perbatasan saling membutuhkan. Perbatasan Indonesia memiliki sejumlah keunggulan diversifikasi hasil alam yang dapat dijual ke Sarawak. Sebaliknya, pihak Sarawak memiliki barangbarang konsumsi yang siap atau jadi, sehingga bisa dibeli oleh penduduk warga perbatasan yang membutuhkannya. Sebab, dengan kedekatan geografis tersebut maka lebih hemat baik dari segi biaya dan jarak tempuh, dibandingkan dengan ke Ibu Kota Kabupaten dalam negeri.

Kelebihan lain dari Cross Border Cooperation tersebut adalah bahwa berbagai program yang dikerjasamakan berbasis kebutuhan riil di lapangan. Sebab berbagai rencana kerjasama yang dibicarakan dalam forum Sosek Malindo tersebut harus berdasarkan kebutuhan riil yang bisa segera dioperasionalkan. Oleh sebab itu, termasuk kelebihan berikutnya dari Sosek Malindo tersebut adalah bahwa programprogram yang dikerjasamakan dalam konteks Indonesia selalu direspon cepat oleh instansi teknis yang dikoordinasikan oleh Badan Pengelola Perbatasan. Dalam konteks ini, Indonesia akan dipandang tidak konsisten oleh negara tetangga manakala kesepakatan-kesepakatan yang dibuat dalam laporan pertemuan Sosek Malindo tidak melaksanakannya. Dengan demikian, di samping program yang diusulkan berbasis kebutuhan, maka program yang sudah disepakati ditindaklanjuti pula dengan cepat.

Berdasarkan hasil kajian ini maka dapat direkomendasikan sebagai berikut. Pertama, pada prinsipnya semangat perubahan paradigmatik dalam pengelolaan perbatasan negara tersebut, seyogyanya diikuti dengan perubahan pendekatan kebijakan teknis yang mendukung paradigma baru dalam pengelolaan perbatasan tersebut. Berbagai hambatan sektoral dalam pelaksanaan pembangunan kawasan perbatasan tersebut dapat di atasi manakala pendekatan regional dalam pengelolaan perbatasan dengan pemberian kewenangan eksekutif terbatas bagi Badan Pengelola Perbatasan. 
Kedua, model Cross Border Approach sebagai alternatif model kebijakan perbatasan dengan berbagai keunggulan yang dimilikinya, bagaimanapun muaranya adalah pada kemampuan pengelola perbatasan di dalam negeri secara efektif dan efisien. Oleh sebab itu, maka payung regulasi bagi jaminan pelaksanaan berbagai kesepakatan kerjasama lintas batas tersebut harus segera disiapkan baik di tingkat pusat maupun di tingkat daerah.

\section{Daftar Pustaka}

Arifin, S., Migrasi Penduduk dan Implikasinya Terhadap Hankam di Wilayah Perbatasan Kalbar-Serawak, Malaysia, Jurnal Masalah-Masalah Hukum, Undip, Jilid 40 No. 2 April 2011.

Association of European Border Region, Contribution of Cross-Border Co-Operation to Implementing The Lisbon Strategy, AEBR Annual Conference, 20-21 October 2005 In Drama, Euroregion Nestos-Mesta.

Badan Nasional Pengelola Perbatasan (BNPP) Republik Indonesia, 2011. Desain Besar (Grand Design) Pengelolaan Batas Wilayah Negara dan Kawasan Perbatasan Tahun 2011-2025, SERI BNPP 01S-0111, Jakarta.

Bappeda, "Program Aksi Pengelolaan Perbatasan Antar Negara Kalimantan Barat". Laporan Kajian, 2007.

Bappenas, Strategi dan Model Pengembangan Wilayah Perbatasan. Laporan Studi Direktorat Pengembangan Kawasan Khusus dan Tertinggal Deputi Bidang Otonomi Daerah dan Pengembangan Regional Badan Perencanaan Pembangunan Nasional, Jakarta, 2003.

Carens, J.H. "Aliens and Citizens: "The Case for Open Border", dalam Kymlicka, The Rights of Minority Cultures, Oxford University Press, New York, 1997.

Cribb dan Ford, Indonesia Byond The Water's Edge: Managing an Archipelagic State. Institute of Southeast Asian Studies, Singapore, 2009.

Direktorat Jenderal Pemerintahan Umum-Departemen Dalam Negeri, "Perbatasan Antar Negara", Makalah dipresentasikan pada acara Seminar Nasional: Pengelolaan Wilayah Perbatasan Dalam Rangka Menjaga Keutuhan Negara Kesatuan Republik Indonesia, diselenggarakan oleh UPN Veteran, Yogyakarta, 18 November 2008.

Evans, M.D., Blackstone's International Law Document, (Fouth Edition), Blackstone's Press Limited, 1999.

Gochhayat, S.A. Social Engineering By Roscoe Pound Issues In Legal and Politacal Philosophy, West Bengal National University Of Juridical Science, Kolkata, (15 November 2010), diakses dalam http://ssrn.com/abstract $=1742165,9$ Februari 2013.

Guo, R., Border-Regional Economics, Heidelberg: PhysicaVerl, Germany, 1996. 
Ibrahim, J., Teori \& Metodologi Penelitian Hukum Normatif, Bayumedia, Malang, 2006.

Kemenkeu, Money Follow Function dalam Penganggaran Berbasis Kinerja, dalam http:/ /www.anggaran.depkeu.go.id/web-content-list.asp?ContentId=247, diakses tanggal 9 Desember 2012.

Kompas, Menerobos Negara Untuk Menjual Hasil Pertanian, 4 April 2008.

Lahnisafitra, I., Kajian Pengembangan Wilayah Pada Kawasan Perbatasan Kalimantan Barat-Sarawak, Thesis Master Teknik Sipil ITB, Bandung, 2005.

Lahnisafitra, I. Pentingnya Kerjasama Sosial Ekonomi Malaysia - Indonesia (Sosek Malindo) dan Kaitannya dengan Pertumbuhan Sub Regional ASEAN (Studi Kasus : Kerjasama Sosek Malindo Tingkat Daerah Kalbar - Sarawak), Makalah dipresentasikan dalam kegiatan Seminar Internasional IndonesiaMalaysia Update, UGM Yogyakarta, 27 - 29 Mei 2008.

Lukito, S. Sutisna, S. dan Sumaryo, Boundary Making Theory dan Pengelolaan Perbatasan di Indonesia, (Makalah) disampaikan pada Workshop Pengelolaan Wilayah Perbatasan, Jurusan Ilmu HI/UPN Veteran, Yogyakarta, 18 Agustus 2008.

Marzuki, P.M., Penelitian Hukum, Prenada Media, Jakarta, 2005.

Moleong, J.L., Metodologi Penelitian Kualitatif, PT. Rosdakarya, Bandung, 2001.

Prescott, V. dan Triggs, G.D.. International Frontiers and Boundaries: Law, Politics and Geography, Martinus Nijhoff Publisher, Leiden, 2008.

Putri, E.I.K., Refungsionalisasi Kecamatan Dalam Perencanaan Pembangunan Wilayah Spasial, Project Working Paper Series No.04, Pusat Studi Pembangunan Pertanian dan Perdesaan, IPB, 2008.

Sandel. J., Justice What's The Right Thing To Do?. Penguin Books, England, 2009.

Sianturi, E.M.T dan Nafsiah, Strategi Pengembangan Perbatasan Wilayah Kedaulatan NKRI; Majalah Balitbang Dephan, Jakarta, 2001.

Supiadi, A., Masalah Penguasaan Tanah di Daerah Perbatasan Indonesia-Malaysia Kaitannya dengan Security Belt: Studi Kasus di Desa Entikong, Kecamatan Entikong, Kabupaten Sanggau, Provinsi Kalimantan Barat, Laporan Penelitian, Badan Pertanahan Nasional, Sekolah Tinggi Pertanahan Nasional, Yogyakarta, 2004.

Sutisna, S. Lokita, S. dan Sumaryo, "Boundary Making Theory dan Pengelolaan Perbatasan di Indonesia", Makalah Dipresentasikan Pada Seminar Pengelolaan Perbatasan, Diselenggarakan Oleh UPN Veteran, Yogyakarta, 16 November 2008.

The Telegraph, Britain Calls For EU's Free Movement Rules To be Suspended, 9 Februari 2013, dalam < http://www.telegraph.co.uk/news/worldnews/europe/eu/ 9132205 /Britain-calls-for-EUs-free-movement-rules-to-be-suspended.html>, diakses tanggal 9 Februari 2013.

Wuryandari, G., Keamanan di Perbatasan Indonesia-Timor Leste: Sumber Ancaman dan Kebijakan Pengelolaannya, Yogyakarta, Pustaka Pelajar dan P2P LIPI, 2009. 
UUD 1945 Pasca Amandemen

Undang-Undang Nomor 43 Tahun 2008 tentang Wilayah Negara

UU No. 27 Tahun 2007 tentang Pengelolaan Wilayah Pesisir dan Pulau-Pulau Kecil

UU No. 26 Tahun 2007 tentang Penataan Ruang

UU No. 32 Tahun 2004 tentang Pemerintahan Daerah

UU No. 3 Tahun 2002 tentang Pertahanan Negara

Undang-undang No. 25 Tahun 2000 tentang Program Pembangunan Nasional (Propenas)

Undang-Undang No. 4 Tahun 1992 tentang Perumahan dan Permukiman

Peraturan Pemerintah No. 26 Tahun 2008 tentang Rencana Tata Ruang Wilayah Nasional (RTRWN)

Peraturan Presiden No. 12 Tahun 2010 tentang Pembentukan Badan Nasional Pengelola Perbatasan

Permendagri No. 2 Tahun 2012 tentang Pedoman Pembentukan Badan Pengelola Perbatasan di Daerah

Permendagri No.12 Tahun 2010 tentang Badan Nasional Pengelola Perbatasan (BNPP)

Permendagri No. 33 Tahun 2008

Keputusan Menteri Keuangan RI Nomor: 490/KMK.05/1996 Perdagangan Lintas Batas.

Pergub Provinsi Kalimantan Barat No. 65 Tahun 2008 tentang BPKPK

Peraturan Kepala BNPP No. 1 Tahun 2011 tentang Grand Design Pembangunan Kawasan Perbatasan 2011-2025

Peraturan BNPP No. 1 Tahun 2012 tentang Rencana Aksi Pengelolaan Batas Wilayah Negara dan Kawasan Perbatasan Tahun 2012

Keputusan Kepala Badan Perencana Pembangunan Daerah (Bappeda) Provinsi Kalimantan Barat No. 2 Tahun 2006 Tentang Pembentukan Tim Teknis dan Sekretariat Kelompok Kerja Sosial Ekonomi Malaysia-Indonesia Tingkat Daerah Kalimantan Barat.

Wawancara dengan Ismintarti, Direktorat Jenderal Pemerintahan Umum, Kementerian Dalam Negeri Republik Indonesia Jakarta.

Wawancara dengan Baihaqi, Direktorat Jenderal Pemerintahan Umum, Kementerian Dalam Negeri Republik Indonesia Jakarta.

Wawancara dengan Bambang W Badan Nasional Pengelola Perbatasan (BNPP) Kementerian Dalam Negeri Jakarta.

Wawancara dengan Manto, Badan Pengelola Kawasan Perbatasan dan Kerjasama Provinsi Kalimantan Barat. 